European

Thyroid Journal
Eur Thyroid J 2020;9:67-72

DOI: $10.1159 / 000504509$
Received: August 12, 2019

Accepted after Revision: November 2, 2019 Published online: November 27, 2019

\title{
Comparison of a Novel Homogeneous Cyclic Amp Assay and a Luciferase Assay for Measuring Stimulating Thyrotropin-Receptor Autoantibodies
}

\author{
Tanja Diana ${ }^{a}$ Paul D. Olivo ${ }^{b}$ Yie-Hwa Chang ${ }^{c}$ Christian Wüster $^{d}$ \\ Michael Kanitz $^{\mathrm{a}}$ George J. Kahaly ${ }^{\mathrm{a}}$ \\ ${ }^{a}$ Molecular Thyroid Research Laboratory, Department of Medicine I, Johannes Gutenberg University (JGU) Medical \\ Center, Mainz, Germany; ${ }^{b}$ Department of Molecular Microbiology, Washington University Medical School, St. Louis,

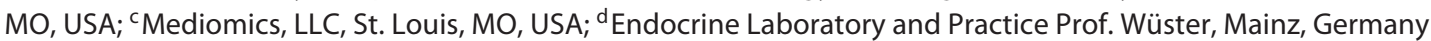

\author{
Keywords \\ Cyclic adenosine monophosphate assay · Cell-based \\ bioassay · Graves' disease · Stimulating \\ thyrotropin-receptor autoantibodies
}

\begin{abstract}
Objective: Stimulating thyrotropin-receptor antibodies (TSAb) cause Graves' disease (GD). We tested a novel homogeneous fluorescent $3^{\prime}, 5^{\prime}$ cyclic adenine monophosphate (cAMP) assay for the detection of TSAb in a bioassay. Methods: Chinese hamster ovary $(\mathrm{CHO})$ cell lines expressing either a chimeric (MC4) or wild-type (WT) TSH-R were incubated with the adenyl cyclase activator forskolin, a human TSAb monoclonal antibody (M22), and with sera from GD patients. Intracellular CAMP levels were measured using a Bridge-lt ${ }^{\circledR}$ CAMP assay, and the results were compared with a luciferase-based bioassay. Results: Both cell lines were stimulated with forskolin concentrations (0.006-200 $\mu \mathrm{M})$ in a dose-dependent manner. The linear range in the MC4 and WT cells was $0.8-25$ and $3.1-50 \mu \mathrm{M}$, respectively. Levels of CAMP and luciferase in forskolin-treated MC4 and WT cells were positively correlated $(r=0.91$ and 0.84 , both $p<0.001)$. The $50 \%$ maximum stimulatory concentration of forskolin was more than 16-fold higher for the CHO-WT cells than the CHO-
\end{abstract}

MC4 cells in the CAMP assay and 4-fold higher in the luciferase assay. Incubation of both cell lines with M22 (0.006-50 $\mathrm{ng} / \mathrm{mL}$ ) resulted in a dose-dependent increase in cAMP levels with linear ranges for the MC4 and WT cells of $0.8-12.5$ and $0.2-3.125 \mathrm{ng} / \mathrm{mL}$, respectively. Comparison of CAMP and luciferase levels in M22-treated MC4 and WT cells also showed a positive correlation $(r=0.88, p<0.001$ and 0.75 , $p=0.002$ ). A positive correlation was also noted when using patient samples $(r=0.96, p<0.001)$ that were all TSH-R-Ab binding assay positive. Conclusion: The novel, rapid, simpleto-perform CAMP assay provides TSAb-mediated stimulatory results comparable to a luciferase-based bioassay.

(c) 2019 European Thyroid Association Published by S. Karger AG, Basel

\section{Introduction}

Autoantibodies against the thyrotropin receptor (TSH-R-Ab) play an important role in the pathogenesis of autoimmune thyroid diseases [1-5]. These functional antibodies demonstrate different effects on the TSH-R and can either stimulate or block the TSH-R [6]. Stimulating TSH-R-Ab (TSAb) mediate the hyperthyroidism of Graves' disease (GD) by activating the $3^{\prime}, 5^{\prime}$ cyclic adenine monophosphate (cAMP) signal transduction pathway

\section{KARGER}

E-Mail karger@karger.com

www.karger.com/etj (c) 2019 European Thyroid Association

Published by S. Karger AG, Basel 
leading to stimulation of thyroid hormone production and proliferation of thyrocytes in an unregulated manner [7-11]. In contrast, blocking TSH-R-Ab (TBAb) bind to the TSH-R and block TSH activation of the cAMP pathway which can lead to hypothyroidism [12-14]. Both TSH-R-Ab activities can be present in the same patient [15]. A number of TSH-R-Ab immunoassays have been developed, but only bioassays for TSH-R-Ab, regardless of the readout used, are able to distinguish between the functional TSH-R-Ab activities [16-18].

The second messenger cAMP is involved in different biological processes; i.e., the regulation of metabolism and transcription $[19,20]$. Early studies on the serum of patients with GD revealed an increase in cAMP production using crude human thyroid-derived plasma membranes [21]. Human thyroid adenyl cyclase (AC) stimulator activity was identified by incubating human thyroid plasma membranes with TSH or IgG from patients with GD and unlabeled adenosine triphosphate [21]. Subsequent studies measured TSAb-induced AC activity using human thyroid plasma membranes and a non-hydrolyzable guanosine triphosphate analogue, guanyl-5'-yl imidodiphosphate [22]. Historically, bioassays for TSAb measured cAMP levels in cells using radioimmunoassays and more recently non-radiometric immunoassays [2327]. To avoid the washing steps of immunoassays and simplify the readout, bioassays employing luciferase expression have been developed for the detection of either TSAb $[2,8,9]$ or TBAb $[12,13]$ using Chinese hamster ovary $(\mathrm{CHO})$ cells expressing a chimeric human TSH-R. In addition, $\mathrm{CHO}$ cells expressing the wild-type (WT) TSH-R and a cAMP-responsive luciferase reporter were utilized to measure TSAb [28] and TBAb [29]. These bioassays are based on the transcription of a luciferase gene controlled by the cAMP-response element-binding protein $[8,12]$. Recently, novel assays have been developed that enable single-step, homogeneous measurement of cyclic AMP levels [30], and novel biosensors have been developed that allow for real-time measurement of cAMP dynamics inside live cells [31-33]. For example, a cyclic nucleotide-gated calcium channel and aequorin was used to develop a live-cell TSAb bioassay [34].

The aim of this study was to directly compare a novel homogeneous fluorescent assay for cAMP with luciferase for measuring TSAb using $\mathrm{CHO}$ cells engineered to express either a WT-TSHR or a chimeric TSHR (MC4) [8, $35,36]$. Levels of cAMP and luciferase were measured following treatment of cells with a nonspecific cAMP inducer, a monoclonal TSAb, and sera from hyperthyroid patients containing TSAb.

\section{Methods}

\section{Subjects}

A total of 33 untreated hyperthyroid patients with GD were enrolled. GD was defined as biochemical hyperthyroidism with positive thyroid-binding inhibitory immunoglobulins (TBII; Cobas e411 analyzer; Roche Diagnostics, Mannheim, Germany) and an enlarged gland with a typical "thyroid storm pattern" on Doppler ultrasound.

\section{Dilutions of Forskolin, M22 MAb Bovine TSH, and Patient} Serum

A stock solution of forskolin (10 mg, Cat \# F6886; Sigma-Aldrich, St. Louis, MO, USA) was prepared at $20 \mathrm{~mm}$ in dimethylsulfoxide (AppliChem GmbH, Darmstadt, Germany) and for M22 $\mathrm{MAb}(4 \mu \mathrm{g}$ of IgG with $2.5 \mathrm{mg}$ of BSA/vial, freeze-dried; Kronus, Star, ID, USA) at $2 \mu \mathrm{g} / \mathrm{mL}$ in phosphate-buffered saline. Both forskolin and M22 MAb were prepared as two-fold dilutions in reaction buffer (RB; Thyretain, Quidel, CA, USA). Bovine TSH (10 IU/ vial; Sigma-Aldrich) concentrations were diluted 1:11 in normal serum. All serum samples from untreated patients with GD were diluted 1:11 in RB.

\section{Genetically Engineered Cell Lines}

$\mathrm{CHO}$ cell lines express either a chimeric (MC4) or WT human TSH-R, as described previously [2]. Both cell lines also contain a firefly luciferase gene under the control of the glycoprotein hormone alpha subunit promoter that contains two binding sites for cAMP-response element-binding protein.

\section{Bioassay for TSAb}

TSAb were measured using a luciferase-based bioassay that utilizes CHO-MC4 cells (Thyretain) according to the manufacturer's instructions. Briefly, $\mathrm{CHO}-\mathrm{MC} 4$ or $\mathrm{CHO}-\mathrm{WT}$ cells were seeded and grown to confluent cell monolayers in 96-well plates for 15$18 \mathrm{~h}$ at $37^{\circ} \mathrm{C}, 5 \% \mathrm{CO}_{2}$. Specimens and three assay controls (positive, reference, and normal) were diluted 1:11 in RB. Therefore, $300 \mu \mathrm{L} \mathrm{RB}$ and $30 \mu \mathrm{L}$ of the sample were mixed, and $100 \mu \mathrm{L}$ were added to the cell monolayer and each plate was incubated for $3 \mathrm{~h}$ at $37^{\circ} \mathrm{C}, 5 \% \mathrm{CO}_{2}$. Each sample was measured in duplicate. Subsequently, the cells were lysed with lysis buffer containing the substrate for the luciferase. The relative light unit (RLU) values were quantified in the luminometer (Tecan Infinite M200; Tecan, Crailsheim, Germany).

\section{Measurement of cAMP}

Intracellular cAMP levels were measured with a homogeneous, fluorescent assay that is based on binding of cAMP to a DNAbinding protein (Bridge-It ${ }^{\circledR}$ cAMP designer fluorescence assay, Cat \# 122934; Mediomics LLC, St. Louis, MO, USA) [30]. The assay principle is based on two DNA fragments, each containing half of the CAMP-dependent DNA-binding protein (CAP) binding site each of which is labeled with a fluorescence donor and a quencher, respectively. The presence of $\mathrm{CAMP}$ induces conformation changes of CAP and greatly increases its binding affinity to the annealed DNA fragments. The annealing of the two DNA fragments brings the probe and quencher into close proximity, resulting in fluorescence quenching. Thus, cAMP levels are inversely proportional to the level of fluorescence.
68

Eur Thyroid J 2020;9:67-72 DOI: $10.1159 / 000504509$
Diana/Olivo/Chang/Wüster/Kanitz/ Kahaly 
When measuring cAMP in the TSAb bioassay, several steps of the bioassay protocol were modified. Both, $\mathrm{CHO}-\mathrm{MC} 4$ and $\mathrm{CHO}-$ WT cells were seeded and grown for $17 \mathrm{~h}$ at $37^{\circ} \mathrm{C}, 5 \% \mathrm{CO}_{2}$. Before addition of samples, each well was pre-filled with $100 \mu \mathrm{L}$ of 3 -isobutyl-1-methylxanthine (IBMX, final concentration in the well $0.75 \mathrm{mM}$ ) solution prepared in RB (Thyretain). Forskolin and M22 samples $(100 \mu \mathrm{L}$ per well) were added in duplicate, and the plate was incubated for $3 \mathrm{~h}$ (forskolin), $30 \mathrm{~min}(\mathrm{M} 22)$ at $37^{\circ} \mathrm{C}, 5 \% \mathrm{CO}_{2}$. All patient serum samples were diluted $1: 11$ in $\mathrm{RB}(30 \mu \mathrm{L}$ serum plus $300 \mu \mathrm{L} \mathrm{RB}$ ) and measured in the CHO-MC4 cell line. Subsequently, $100 \mu \mathrm{L}$ of the cAMP designer assay solution was added according to the manufacturer's instructions (Mediomics LLC). The plate was covered with tinfoil and incubated for further $30 \mathrm{~min}$ on an orbital shaker at room temperature. The solutions were transferred to a whole black 96-well plate, and the absolute fluorescence (excitation $\sim 485 \mathrm{~nm}$, emission $\sim 540 \mathrm{~nm}$ ) values were quantified in a fluorescence plate reader (Tecan Infinite M200). Each sample was measured in duplicate and independently repeated at least three times. The relative fluorescence $(R F)$ values were calculated based on the raw fluorescence data as follows: RF = $(\mathrm{F} 0-\mathrm{F}) / \mathrm{F} 0 . \mathrm{F} 0=$ fluorescent intensity of the blank or buffer control, $\mathrm{F}=$ fluorescent intensity of the sample. The occurrence of fluorescence quenching leads to a reduction of the fluorescence intensity.

\section{Statistical Analysis}

Data were presented as mean \pm standard error (SEM). Experimental data were statistically analyzed with SPSS version 23 (SPSS, Chicago, IL, USA) and Graph Pad Prism software, Inc. (version 5.04), San Diego, CA, USA. Correlations were verified with either Spearman's or Pearson's test. A result was significant when $p<0.05$.

\section{Results}

The demographic and serological data of all 33 untreated patients with Graves' hyperthyroidism are shown in Table 1.

\section{cAMP and Luciferase Levels following Nonspecific Stimulation with Forskolin}

Intracellular levels of cAMP and luciferase in CHOMC4 and CHO-WT cells were measured following incubation with forskolin, an adenyl cyclase stimulator, at concentrations from 0.006 up to $200 \mu \mathrm{M}$ (online suppl. Fig. 1; for all online suppl. material, see www. karger.com/doi/10.1159/000504509). In the Bridge-It assay, the linear range was from 0.8 to $25 \mu \mathrm{M}$ for the $\mathrm{CHO}$ MC4 cells and from 3.1 to $50 \mu \mathrm{M}$ for the CHO-WT cells (online suppl. Fig. 1a). In the luciferase assay, the linear range was from 0.09 to $6.25 \mu \mathrm{M}$ with the $\mathrm{CHO}-\mathrm{MC} 4$ cells and from 0.19 to $3.125 \mu \mathrm{M}$ for the CHO-WT cells (online suppl. Fig. 1b). There was a high correlation between the two assays for both cell lines (CHO-MC4: Spearman's $r=$ $0.91, p<0.001$ and CHO-WT: Spearman's $r=0.84, p<$
Table 1. Demographic and serological data of untreated patients with GD

$\begin{array}{lc}N & 33 \\ \text { Gender }(\mathrm{F} / \mathrm{M}) & 24 / 9 \\ \text { Age, years } & 59 \pm 3 \\ \text { TSH }(0.27-4.2 \mu \mathrm{IU} / \mathrm{mL}) & 0.00 \pm 0.01 \\ \text { fT3 }(3.1-6.8 \mathrm{pmol} / \mathrm{L}) & 14.9 \pm 1.3 \\ \text { fT4 }(12-22 \mathrm{pmol} / \mathrm{L}) & 27 \pm 1.9 \\ \text { TBII }(<1.75 \mathrm{IU} / \mathrm{L}) & 37 \pm 53 \\ \text { TSAb luciferase bioassay }(\mathrm{RLU}) & 8,068 \pm 1,700 \\ \text { cAMP Bridge-It assay }(\mathrm{RF} \%) & 74 \pm 2\end{array}$

Number $(N)$ and mean \pm SEM values are shown. RF\% = percentage of relative fluorescence.

$0.001)$. The $50 \%$ maximum stimulatory concentration of forskolin was more than 16-fold higher for the CHO-WT cells than the CHO-MC4 cells in the cAMP assay and 4 -fold higher in the luciferase assay.

\section{Dose-Response Curve after Incubation with Bovine TSH}

Different concentrations of bovine TSH between 3.125 and 3,000 $\mathrm{mIU} / \mathrm{L}$ were measured in both assays (online suppl. Fig. 2a, b).

\section{Dose-Response Curve after Incubation with the \\ Specific Stimulator M22 MAb}

Intracellular levels of cAMP and luciferase in both $\mathrm{CHO}$ cell lines were measured following incubation of the cells with the human TSH-R-stimulating MAb M22 at concentrations from 0.006 to $50 \mathrm{ng} / \mathrm{mL}$ (Fig. 1). In the cAMP assay, the linear ranges for the $\mathrm{CHO}-\mathrm{MC} 4$ and CHO-WT cells were from 0.8 to $12.5 \mathrm{ng} / \mathrm{mL}$ and from 0.2 to $3.125 \mathrm{ng} / \mathrm{mL}$, respectively (Fig. 1a). Similar dose-response curves for both $\mathrm{CHO}$ cell lines after M22 stimulation were seen with the luciferase bioassay (Fig. 1b). There was a high correlation in the CHO-MC4 cells between the cAMP assay and the luciferase assay (Spearman's $r=0.88, p<0.001$ ); however, the correlation between the assays was somewhat lower with the CHO-WT cell line (Spearman's $r=0.75, p=0.002$ ). Higher levels of both cAMP and luciferase were induced in the CHOMC4 cells compared to the CHO-WT cells.

\section{Measurement of cAMP and Luciferase Levels after Incubation with Sera from GD Patients}

All 33 polyclonal serum samples from untreated hyperthyroid patients with GD were measured in both the 


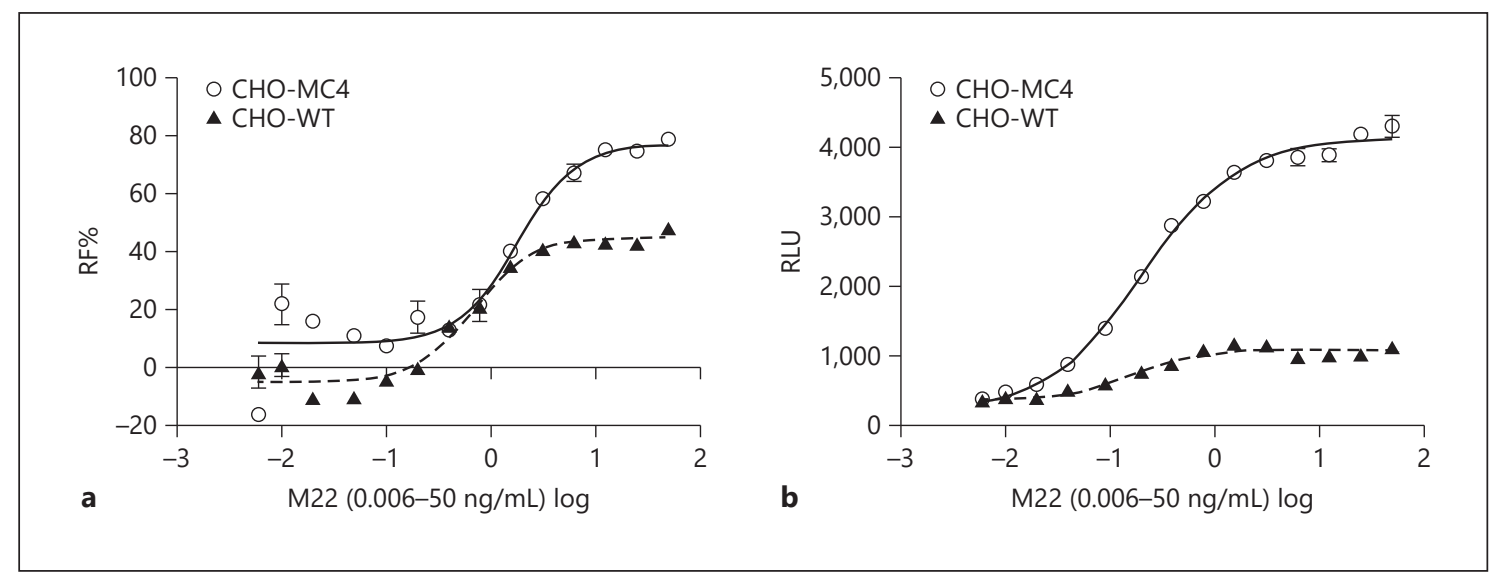

Fig. 1. a Dose-response curve of M22 MAb in the CHO-MC4 and $\mathrm{CHO}-\mathrm{WT}$ cells measured in the cAMP assay. On the $\mathrm{x}$-axis, the M22 MAb concentrations $(0.006-50 \mathrm{ng} / \mathrm{mL})$ are presented in a logarithmic scale, and on the $y$-axis, there is RF\%. The outlined circles represent the data for the $\mathrm{CHO}-\mathrm{MC} 4$ cells, and the black triangles present those for the $\mathrm{CHO}$-WT cells. The induction time was $30 \mathrm{~min}$. All M22 MAb concentrations were measured in duplicate, and values are shown as mean \pm SEM. b Dose-response

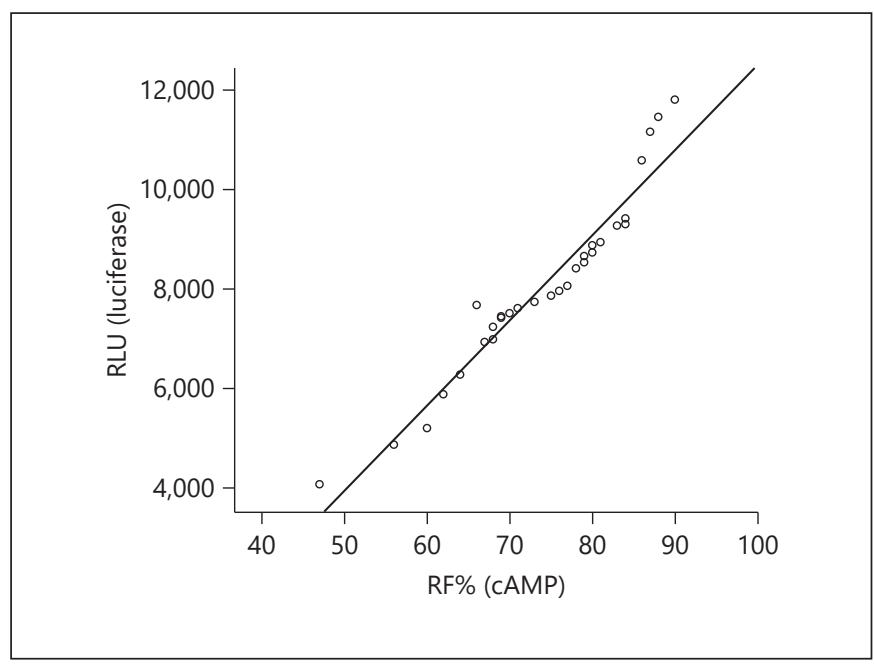

Fig. 2. Correlation of results of the luciferase and cAMP TSAb bioassays using serum from 33 untreated patients with GD. The Bridge-It cAMP assay results are shown on the $\mathrm{x}$-axis as RF\% values, and the luciferase results are shown on the y-axis as RLU values. In both assays, $\mathrm{CHO}-\mathrm{MC} 4$ cells were used. All serum samples were also TSH-R-Ab binding assay positive.

cAMP Bridge-It assay and in the luciferase bioassay using CHO-MC4 cells (Fig. 2). The percentage of RF (RF\%) and RLU obtained by the cAMP Bridge assay and the luciferase bioassay correlated positively $(r=0.96, p<0.001)$. All curve of M22 MAb in CHO-MC4 and CHO-WT cells measured in the luciferase bioassay. On the $\mathrm{x}$-axis, the M22 MAb concentrations $(0.006-50 \mathrm{ng} / \mathrm{mL})$ are presented in a logarithmic scale, and on the $y$-axis, there are the RLU values. The outlined circles represent the data for the $\mathrm{CHO}-\mathrm{MC} 4$ cells, and the black triangles represent those for the CHO-WT cells. The induction time was $3 \mathrm{~h}$. All M22 MAb concentrations were measured in duplicate, and values are shown as mean \pm SEM. serum samples were positive when measured with a TSH$\mathrm{R}-\mathrm{Ab}$ binding immunoassay (TBII, Cobas e411; Roche). Further 50 GD samples were tested with both cAMP and luciferase assays and yielded similar results. All samples were also measured with the Cobas binding assay and were TBII positive

\section{Discussion}

In the present work, in a cell-based bioassay for TSAb, a novel, simple-to-perform, homogeneous, fluorescencebased cAMP assay was evaluated and compared to a luciferase assay using both polyclonal TSHR-Ab sera from hyperthyroid GD patients as well as monoclonal TSHRAb. This novel Bridge-It cAMP assay offers several advantages; i.e., ease-of-use and a wide linear range. Most importantly, the assay is homogeneous in that there are no washing steps. This greatly simplifies the assay protocol compared to most cAMP assays that involved the use of radioisotopes and/or immunoassays [21, 22, 37, 38].

The performance of the cAMP assay was first evaluated using an activator of $\mathrm{AC}$, forskolin, which nonspecifically raises intracellular cAMP levels. As measured by the Bridge-It cAMP assay, forskolin increased cAMP levels in both $\mathrm{CHO}$ cell lines in a dose-dependent manner. In the $\mathrm{CHO}-\mathrm{MC} 4$ cell line that is used in the FDA-cleared 
Thyretain luciferase-based bioassay, the $50 \%$ maximum concentration of forskolin was much lower compared to the $\mathrm{CHO}-\mathrm{WT}$ cell line. This is an interesting result because forskolin acts independently of the TSH-R and, therefore, this result cannot be attributed to differences in the structure of the two receptors or the number of receptors per cell. In contrast, studies with the stimulating human monoclonal antibody (M22) [39] allow for comparison of the signal transduction of the two TSH-R. When stimulating with M22 MAb, the CHO-MC4 cells produced higher levels of cAMP and exhibited a broader linear range compared to the $\mathrm{CHO}-\mathrm{WT}$ cells. Furthermore, differences were also detected in the dose-response curves in the cAMP assay and the luciferase bioassay after incubation of the CHO-MC4 cells with M22 MAb. As previously reported $[12,13]$, the $\mathrm{CHO}-\mathrm{MC} 4$ cells were more sensitive at detecting M22 MAb in the luciferase bioassay compared to the CHO-WT cells, and this was also the case with the CAMP assay. Based on this enhanced sensitivity and lower EC values [12], the chimeric cell line has been used since then to further develop and optimize the luciferase cell-based bioassay. Indeed, the obtained data with the novel cAMP assay confirm our experience and results with both cell lines and suggest that the basis for these observed differences is probably not related to the chimeric TSH-R alone.

When measuring polyclonal patient sera, the data obtained in the two assays expressed as RF\% and RLU showed a high correlation. The Bridge-It cAMP assay directly measures the amount of existing cAMP after cell lysis. In contrast, the luciferase bioassay measures cAMPinduced expression of the luciferase reporter gene that needs a longer induction time to initiate the gene transcription and translation. The advantage of the more time-consuming luciferase assay is that the signal is amplified, which may enable greater sensitivity compared to the cAMP assay. There has been concern, however, that the luciferase readout, being an indirect measure of cAMP induction, might not correlate with direct measurement of cAMP when detecting TSAb. The positive correlation between the two assays with high $r$ values of forskolin and M22 for both CHO cell lines demonstrates that this concern is not justified. Nevertheless, the data of the present study indicates that the homogeneous cAMP assay is an acceptable alternative for the detection of TSAb and allows the quantitative measurement of M22 MAb TSAb activity. Currently, a prospective study of serum samples from patients with untreated GD with different titers of TSAb is ongoing.

In conclusion, measurement of TSAb in a cell-based bioassay using a novel, homogeneous cAMP assay provides equivalent TSAb measurements compared to a luciferase-based bioassay.

\section{Acknowledgments}

We thank Nora Lachhein, Marie Nitsch, and Felix Pavenstädt (laboratory associates, JGU Thyroid Laboratory) for their valuable experimental help.

\section{Statement of Ethics}

This study was consistent with the Declaration of Helsinki, and the written informed consent was approved by the local ethics committee. This research complies with the guidelines for human studies.

\section{Disclosure Statement}

T.D., M.K., and C.W. have nothing to disclose. Y.-H.C. is the President of Mediomics, USA. P.D.O. and G.J.K. consult for Mediomics and Quidel, USA, and the JGU laboratory has received research-associated funding from Quidel, USA.

\section{References}

1 Diana T, Brown RS, Bossowski A, Segni M, Niedziela M, König J, et al. Clinical relevance of thyroid-stimulating autoantibodies in pediatric graves' disease-a multicenter study. J Clin Endocrinol Metab. 2014 May;99(5):1648-55.

2 Diana T, Kanitz M, Lehmann M, Li Y, Olivo PD, Kahaly GJ. Standardization of a bioassay for thyrotropin receptor stimulating autoantibodies. Thyroid. $2015 \mathrm{Feb}$;25(2):169-75.

3 Kahaly GJ, Bartalena L, Hegedüs L, Leenhardt L, Poppe K, Pearce SH. 2018 European Thyroid Association Guideline for the Manage- ment of Graves' Hyperthyroidism. Eur Thyroid J. 2018 Aug;7(4):167-86.

4 Diana T, Daiber A, Oelze M, Neumann S, Olivo PD, Kanitz M, et al. Stimulatory TSHReceptor Antibodies and Oxidative Stress in Graves Disease. J Clin Endocrinol Metab. 2018 Oct;103(10):3668-77.

5 Stożek K, Bossowski A, Ziora K, Bossowska A, Mrugacz M, Noczyńska A, et al. Functional TSH receptor antibodies in children with autoimmune thyroid diseases. Autoimmunity. 2018 Mar;51(2):62-8.
6 Kahaly GJ, Diana T. TSH Receptor Antibody Functionality and Nomenclature. Front Endocrinol (Lausanne). 2017 Feb;8: 28.

7 Lytton SD, Kahaly GJ. Bioassays for TSH-receptor autoantibodies: an update. Autoimmun Rev. 2010 Dec;10(2):116-22.

8 Lytton SD, Li Y, Olivo PD, Kohn LD, Kahaly GJ. Novel chimeric thyroid-stimulating hormone-receptor bioassay for thyroid-stimulating immunoglobulins. Clin Exp Immunol. 2010 Dec;162(3):438-46. 
9 Leschik JJ, Diana T, Olivo PD, König J, Krahn $\mathrm{U}, \mathrm{Li} \mathrm{Y}$, et al. Analytical performance and clinical utility of a bioassay for thyroid-stimulating immunoglobulins. Am J Clin Pathol. 2013 Feb;139(2):192-200.

10 Diana T, Kahaly GJ. Thyroid Stimulating Hormone Receptor Antibodies in Thyroid Eye Disease-Methodology and Clinical Applications. Ophthal Plast Reconstr Surg. 2018 Jul/Aug;34(4S Suppl 1):S13-9.

11 Kahaly GJ, Wüster C, Olivo PD, Diana T. High Titers of Thyrotropin Receptor Antibodies Are Associated With Orbitopathy in Patients With Graves Disease. J Clin Endocrinol Metab. 2019 Jul;104(7):2561-8.

12 Li Y, Kim J, Diana T, Klasen R, Olivo PD, Kahaly GJ. A novel bioassay for anti-thyrotrophin receptor autoantibodies detects both thyroid-blocking and stimulating activity. Clin Exp Immunol. 2013 Sep;173(3):390-7.

13 Diana T, Li Y, Olivo PD, Lackner KJ, Kim H, Kanitz M, et al. Analytical Performance and Validation of a Bioassay for Thyroid-Blocking Antibodies. Thyroid. 2016 May;26(5): 734-40.

14 Diana T, Olivo PD, Kahaly GJ. Thyrotropin Receptor Blocking Antibodies. Horm Metab Res. 2018 Dec;50(12):853-62.

15 Evans M, Sanders J, Tagami T, Sanders P, Young S, Roberts E, et al. Monoclonal autoantibodies to the TSH receptor, one with stimulating activity and one with blocking activity, obtained from the same blood sample. Clin Endocrinol (Oxf). 2010 Sep;73(3):40412.

16 Diana T, Wüster C, Kanitz M, Kahaly GJ Highly variable sensitivity of five binding and two bio-assays for TSH-receptor antibodies. J Endocrinol Invest. 2016 Oct;39(10):1159-65.

17 Diana T, Wüster C, Olivo PD, Unterrainer A, König J, Kanitz M, et al. Performance and Specificity of 6 Immunoassays for TSH Receptor Antibodies: A Multicenter Study. Eur Thyroid J. 2017 Sep;6(5):243-9.

18 Allelein S, Diana T, Ehlers M, Kanitz M, Hermsen D, Schott M, et al. Comparison of a Bridge Immunoassay with Two Bioassays for Thyrotropin Receptor Antibody Detection and Differentiation. Horm Metab Res. 2019 Jun;51(6):341-6.

19 De Cesare D, Sassone-Corsi P. Transcriptional regulation by cyclic AMP-responsive factors. Prog Nucleic Acid Res Mol Biol. 2000;64 343-69.
20 Sands WA, Palmer TM. Regulating gene tran scription in response to cyclic AMP elevation. Cell Signal. 2008 Mar;20(3):460-6.

21 Orgiazzi J, Williams DE, Chopra IJ, Solomon DH. Human thyroid adenyl cyclase-stimulating activity in immunoglobulin $\mathrm{G}$ of patients with Graves' disease. J Clin Endocrinol Metab. 1976 Feb;42(2):341-54.

22 Macchia E, Carayon P, Fenzi GF, Lissitzky S, Pinchera A. A sensitive method for assaying thyroid stimulating immunoglobulins of Graves' disease: use of the guanyl nucleotideamplified thyroid adenylate cyclase assay. Acta Endocrinol (Copenh). 1983 Jul;103(3): $345-51$.

23 Kasagi K, Konishi J, Iida Y, Ikekubo K, Mori $\mathrm{T}$, Kuma $\mathrm{K}$, et al. A new in vitro assay for human thyroid stimulator using cultured thyroid cells: effect of sodium chloride on adenosine $3^{\prime}, 5^{\prime}$-monophosphate increase. J Clin Endocrinol Metab. 1982 Jan;54(1):108-14.

24 Vitti P, Valente WA, Ambesi-Impiombato FS, Fenzi GF, Pinchera A, Kohn LD. Graves' IgG stimulation of continuously cultured rat thyroid cells: a sensitive and potentially useful clinical assay. J Endocrinol Invest. 1982 MayJun;5(3):179-82.

25 Chiovato L, Vitti P, Bendinelli G, Santini F, Fiore E, Capaccioli A, et al. Detection of antibodies blocking thyrotropin effect using Chinese hamster ovary cells transfected with the cloned human TSH receptor. J Endocrinol Invest. 1994 Nov;17(10):809-16.

26 Botero D, Brown RS. Bioassay of thyrotropin receptor antibodies with Chinese hamster ovary cells transfected with recombinant human thyrotropin receptor: clinical utility in children and adolescents with Graves disease. J Pediatr. 1998 Apr;132(4):612-8.

27 Morgenthaler NG, Pampel I, Aust G, Seissler J, Scherbaum WA. Application of a bioassay with $\mathrm{CHO}$ cells for the routine detection of stimulating and blocking autoantibodies to the TSH-receptor. Horm Metab Res. 1998 Mar;30(3):162-8.

28 Evans C, Morgenthaler NG, Lee S, Llewellyn DH, Clifton-Bligh R, John R, et al. Development of a luminescent bioassay for thyroid stimulating antibodies. J Clin Endocrinol Metab. 1999 Jan;84(1):374-7.

29 Jordan NJ, Rinderle C, Ashfield J, Morgenthaler NG, Lazarus J, Ludgate M, et al. A luminescent bioassay for thyroid blocking antibodies. Clin Endocrinol (Oxf). 2001 Mar; 54(3):355-64.
30 Tian L, Wang RE, Fei Y, Chang YH. A homogeneous fluorescent assay for cAMP-phosphodiesterase enzyme activity. J Biomol Screen. 2012 Mar;17(3):409-14.

31 Binkowski B, Fan F, Wood K. Engineered luciferases for molecular sensing in living cells. Curr Opin Biotechnol. 2009 Feb;20(1):14-8.

32 Dupriez VJ, Maes K, Le Poul E, Burgeon E, Detheux M. Aequorin-based functional assays for G-protein-coupled receptors, ion channels, and tyrosine kinase receptors. Receptors Channels. 2002;8(5-6):319-30.

33 Kumar BA, Kumari P, Sona C, Yadav PN. GloSensor assay for discovery of GPCR-selective ligands. Methods Cell Biol. 2017;142:2750.

34 Araki N, Iida M, Amino N, Morita S, Ide A, Nishihara E, et al. Rapid bioassay for detection of thyroid-stimulating antibodies using cyclic adenosine monophosphate-gated calcium channel and aequorin. Eur Thyroid J. 2015 Mar;4(1):14-9.

35 Tahara K, Ban T, Minegishi T, Kohn LD. Immunoglobulins from Graves' disease patients interact with different sites on TSH receptor/ LH-CG receptor chimeras than either TSH or immunoglobulins from idiopathic myxedema patients. Biochem Biophys Res Commun. 1991 Aug; 179(1):70-7.

36 Tahara K, Ishikawa N, Yamamoto K, Hirai A, Ito $\mathrm{K}$, Tamura $\mathrm{Y}$, et al. Epitopes for thyroid stimulating and blocking autoantibodies on the extracellular domain of the human thyrotropin receptor. Thyroid. 1997 Dec;7(6):86777.

37 Vitti P, Rotella CM, Valente WA, Cohen J, Aloj SM, Laccetti P, et al. Characterization of the optimal stimulatory effects of graves' monoclonal and serum immunoglobulin G on adenosine $3^{\prime}, 5^{\prime}$-monophosphate production in fRTL-5 thyroid cells: a potential clinical assay. J Clin Endocrinol Metab. 1983 Oct; 57(4):782-91

38 Michelangeli VP, Munro DS, Poon CW, Frauman AG, Colman PG. Measurement of thyroid stimulating immunoglobulins in a new cell line transfected with a functional human TSH receptor (JPO9 cells), compared with an assay using FRTL-5 cells. Clin Endocrinol (Oxf). 1994 May;40(5):645-52.

39 Sanders J, Evans M, Premawardhana LD, Depraetere $\mathrm{H}$, Jeffreys J, Richards $\mathrm{T}$, et al. $\mathrm{Hu}$ man monoclonal thyroid stimulating autoantibody. Lancet. 2003 Jul;362(9378):126-8. 